\title{
A Conceptual Framework on the Financial Statement Disclosure in Indonesia Local Government
}

\author{
Oktavia Nurlianto, Khoirul Aswar \\ Universitas Pembangunan Nasional Veteran Jakarta, Indonesia \\ oktavianurlianto@yahoo.co.id, aswar_law@yahoo.com
}

\begin{abstract}
This research begins with the problem of the Indonesian Minister of Finance recognizing cities and districts in Indonesia have a low level of compliance regarding financial reports and the Supreme Audit Board (BPK) has published a report that highlights compliance issues in the local government of Indonesia based on the Summary of First Semester Examination Results in 2019 there is a problem of the level of compliance of local government related to the disclosure of financial statements in Indonesia. The purpose of this study was to determine the factors influencing the degree of mandatory disclosure to local governments in Java and Sumatra Islands. This study has three objectives namely to find out the number of local parliamentarians, local government budget spending, existence of an assistance and training program for disclosure financial statement. Therefore, this research contributes to provide an illustration for local governments in measuring financial statement disclosures.
\end{abstract}

Keywords: Disclosure, number of local parliamentarians, budget expenditure, assistance and training program.

\section{Introduction}

Disclosure shall be deemed to be a communication of financial and non-financial, quantitative or otherwise economic information, regarding the position and financial performance of companies (Healy \& Palepu, 2001). A significant issue relating to this research is the acknowledgment by the Indonesian Ministry of Finance that Indonesia's cities and municipalities have a low level of compliance with financial reports (Kompas, 2010) and the Issue of Law no. 22 of 1999 on local government which calls for better accountability. In addition, the Supreme Audit Board of Indonesia (BPK) in 2019 believes that regional financial reports in Indonesia have not met expectations (BPK, 2019). They stated that many local of Indonesia did not prepare thoroughly financial reports based on the standards and regulations. BPK has published a series of reports that highlight compliance issues in Indonesia's local government presented in a graph below:

\section{Figure 1: Compliance Issues in Indonesia}

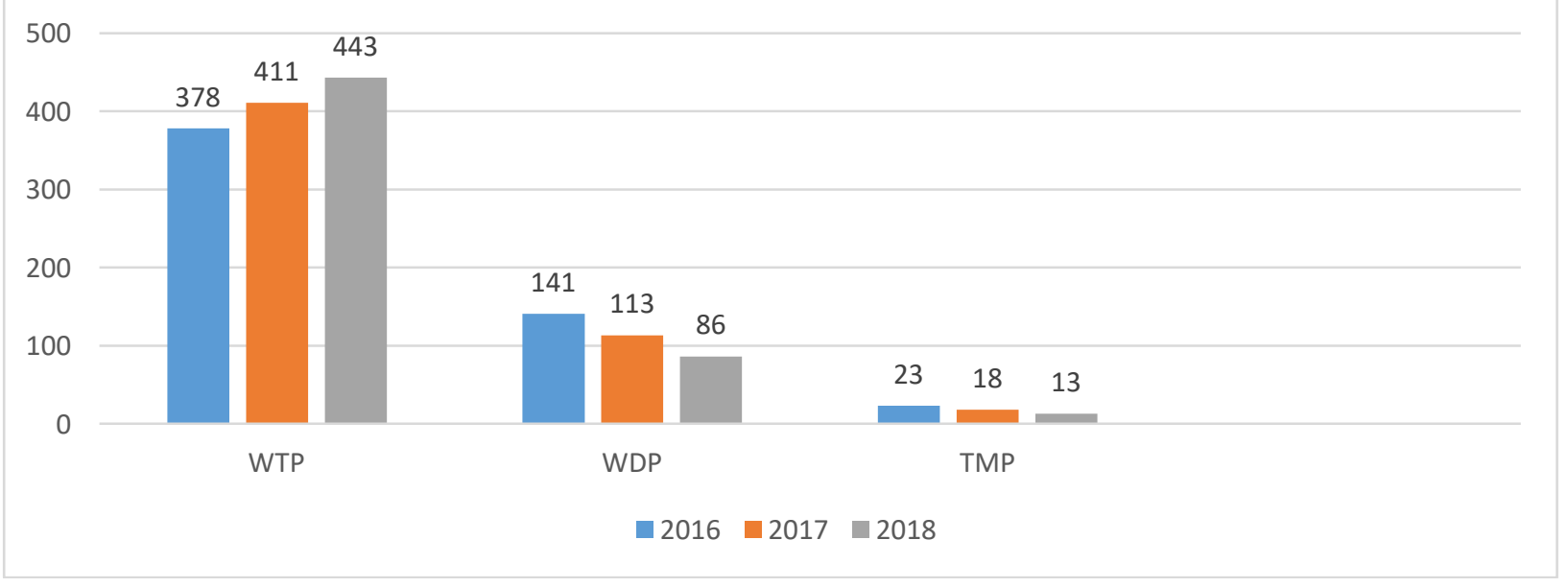

In Figure 1 based on the above explains that the 2019 Semester Examination Results (IHPS) 1, namely the Audit Board of Indonesia (BPK) has examined 542 approximately (100\%) LKPD in 2018. Of these, the BPK gave an unqualified opinion (WTP) namely 443 LKPD around (82\%), fair opinion with the exception (WDP) that is 86 LKPD around (16\%), opinion does not give an opinion (2\%). Based on the level of governance the achievement of WTP opinion has exceeded the target of regional financial performance in the field of strengthening local government governance set in the 2015-2019 RPJMN. Based on the results of the First 
Semester Examination Results (IHPS) in 2019, there is issue with the degree of regional government enforcement related to the extent of transparency of the financial statements in Indonesia. Based on WDP and TMP, as many as 99 LKPD did not receive an opinion from WTP in 2018, because there are accounts in a financial statement that are not reported.

In compliance with the government accounting standard and are not backed by adequate evidence including current assets (19\%) in 48 regional governments, fixed assets (31\%) in 78 LGs, other assets (9\%) in 24 LGs, revenue (3\%) in 7 LGs, operating expenditure (14\%) in 34 LGs, capital expenditure (14\%) in 34 LGs, accounts others, (10\%) in 26 local governments. In addition, the results of BPK's examination revealed that 7,398 findings that contained 12,117 for 2 problems were (1internal control system issues of 5,858 consisting of deficiencies in the internal control mechanism of 1,279 , flaws in the reporting and accounting control system of 1,826 and deficiencies in the management system of expenditure and revenue budget execution of 2,753 and (2) 6,259 non-compliance with legislative requirements of the Rp. 2.19 trillion, consisting of 2,642 loss problems, 2,258 administrative irregularities, 426 potential loss problems, and 933 revenue shortages. The level of disclosure also received support for a number of International studies including the average score of mandatory disclosure practices compared to other previous research in different business organizations such as Glaum and Matsusaka (2001) in Germany (84.0\%, with 153 items); Wallace and Naser (1995) in Hong Kong (73\%, with 142 items); Ali, Ahmed and Henry (2004) in India, Pakistan and Bangladesh (80\%, with 131 items); Owusu-Ansah (1998) in Zimbabwe (75.0\%, with 214 items); Hasan, Karim and Quayes (2008) in Bangladesh (85\%, with 57 items). The level of local financial statements disclosure varies.

In general, disclosure of Indonesia local financial reports is still small. According to Hendriyani and Tahar (2015) the average level of disclosure during 2012 to 2014 was $41.7663 \%$, Suhardjanto and Yulianingtyas (2011) the average level of disclosure was 30.85\%, Martani and Lestiani, (2012) found that the level of disclosure had an average of 35.45\%, and Suhardjanto and Lesmana, (2010) average mandatory disclosure rate of 22\%. Meanwhile Marsella and Aswar (2019) conducted study in Sumatera and found that the level of disclosure was $82,7 \%$. Similar to the financial statements disclosure, there are several studies that show factors affecting on the disclosure of financial statements, namely the number of local parliamentarians (Arifin, 2014; Gilligan \& Matsusaka, 2001; Hix, Noury \& Roland, 2005; Laswad, Fisher \& Oyelere, 2005; Suhardjanto \& Yulianingtyas, 2011), local government budget expenditure (Hilmi \& Martani 2012; Patrick 2007; Friedman 2013), and the existence of an assist and training program (Bushman \& Smith, 2001; Ball, 2001; Lambert, Leuz \& Verrecchia, 2007). This study is intended to contribute to the literature on the factors affecting the disclosure of financial statements in the accounting and public sectors. This research is a form of development from Arifin, (2014) where the research suggests to researchers that future research can be explored by investigating and adding variables such as the number of local governments.

\section{Literature Review and Hypothesis Development}

Effect of Number of Local Parliamentarians on Financial Statement Disclosure: The legislative board or also called the legislature, in language is an advisory body usually elected or electively empowered to make, change or revoke laws from the State or region or branch of government that has power to make laws that are distinguished from the executive and judiciary. The position of a legislative member can be seen as an individual who represents the interests of the voters as well as the interests of his political party (Stigler, 1976). Suhardjanto and Yulianingtyas (2011), Laupe \& Saleh (2018), Gilligan and Matsusaka (2001), Arifin, Tower and Porter (2013) found that there was a positive relationship with financial statement disclosure. This results gives evidence that coercive pressure still needed in Indonesia to increase transparency so it is consistent with the arguments of that coercive pressure is effective in developing countries (Graham \& Woods, 2006). Based on the above explanation, then the hypothesis can be formulated as follows:

H1: Number of local parliamentarians significantly and positively influences financial statement disclosure.

Effect of Local Government Budget Expenditure on Financial Statement Disclosure: Mulyadi (2008: 69) states that the government budget is quantitatively expressed work plan, measured in standard monetary units and other units of measurement spanning a one-year cycle. Patrick (2007), Friedman (2013), Hendriyani and Tahar (2015), Hilmi and Martani (2012), Ingram and DeJong (1984), Gore (2004), Puspita and Martani (2012) found that there was a positive relationship with disclosure of financial statements. So 
that municipal government spending has the ability to force mandatory disclosure practices in financial reporting from regional government. Moreover, this research takes regional government spending as a possible factor in understanding the volatility of mandatory disclosure. Based on the above presumptions, the below hypothesis is formulated:

H2: Local government budget expenditure significantly and positively influences financial statement disclosure.

Effect of Presence of an Assistance and Training Program on Financial Statement Disclosure: According to Kaswan (2012), assistance is a partnership between trainers and employees that focuses on continuous learning, growth and improvement, results in the development of the internal resource needs. This study examines the size of the independent variable presence and training program within the framework of mimetic isomorphism. In the local government the research by Aswar and Saidin, (2018a; 2018b) found that training has a significant with the adoption of accrual accounting. Furthermore, Arifin, (2014), Ramandei Rohman, Ratmono, and Ghozali (2019), Suhardjanto and Yulianingtyas (2011), found that there was a positive relationship with financial statement disclosure. Therefore, based on the above deductions, the below hypothesis is postulated:

H3: The Presence of assistance and training program significantly and positively influences the disclosure of financial statements.

Figure 1: Research Framework

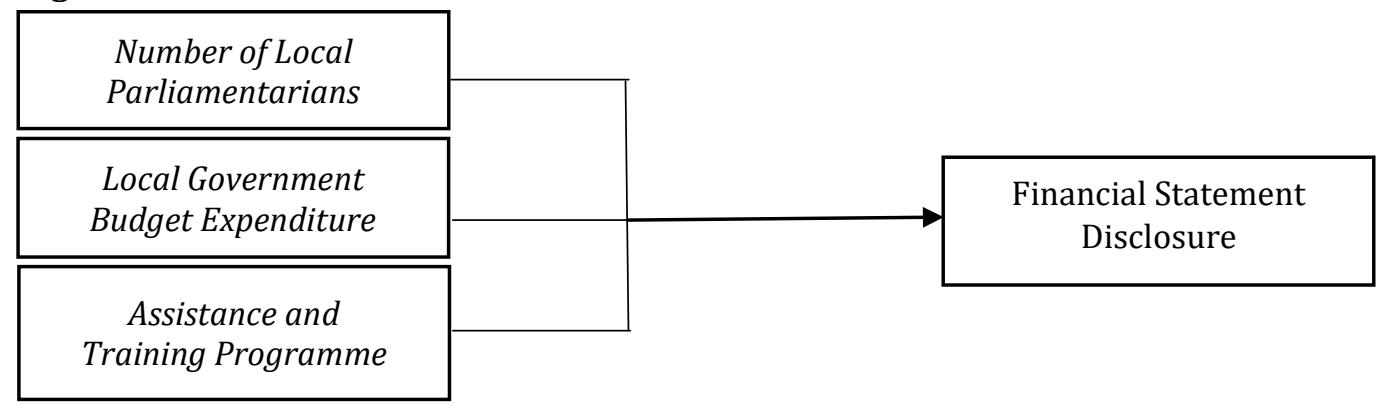

\section{Proposed Method}

This study recommends an appropriate method for testing the factors influencing the level of mandatory disclosure. This study using secondary data from local government financial statements in Indonesia. Data in this study are in the form of financial statements audited by the BPK in 2018. Furthermore, the sample in this study is 80 local governments in Java and Sumatra, and total of sample this study are 80 samples. Java and Sumatera as samples of this study because not all local governments in Java and Sumatra have strong financial accountability at the district and city level. Furthermore, data analysis in this study proposed with using multiple regression analysis.

Table 1: List of Java and Sumatera Islands

\begin{tabular}{lll}
\hline Islands & Province & Total District and City \\
\hline Java & West Jawa & 8 \\
& Central Jawa & 9 \\
& DI Yogyakarta & 5 \\
\multirow{3}{*}{ Sumatra } & East Jawa & 10 \\
& Banten & 8 \\
& Aceh & 4 \\
& North Sumatera & 4 \\
& West Sumatera & 5 \\
& Riau & 4 \\
& Kepulauan Riau & 4 \\
& Jambi & 4 \\
\hline
\end{tabular}


Bengkulu

Lampung

Total
3

4

3

80

\section{Conclusion}

The conceptual paper in this study aims to investigate the influencing factors on the level of local government disclosure, especially local governments in Java and Sumatra. This is important because many local governments in Indonesia have not fully prepared financial reports regarding with regulations and standards so that there is a problem regarding the level of local government compliance with the level of financial statement disclosure in Indonesia. In addition, the Supreme Audit Board of Indonesia (BPK) is responsible for auditing the state's financial statements, including the execution of central and regional budgets, state-owned enterprises (SOEs), and local government owned companies. Factors that influence the level of financial statement disclosure are measured by 50 items of financial statement disclosure. This result is expected the three hypotheses are significantly and positively influences the financial government disclosure. The findings of this study are expected to contribute significantly to the local governments, especially local governments in Java and Sumatra islands in implementing government accounting based on accrual accounting systems and by providing empirical evidence related to much information that must be disclosed as a form of government accountability also can increase disclosure of financial statements in full, enough and reasonable.

\section{References}

Ali, M. J., Ahmed, K. \& Henry, D. (2012). Disclosure Compliance with National Accounting Standards by Listed Companies in South Asia. Accounting and Business Research, November 2014, 34(3), 37-41.

Arifin, J. (2014). Isomorphic Pressures Influencing the Level of Mandatory Disclosure within Financial Statements of Indonesian Local Governments. November, School of Accounting, 1-251.

Arifin, J., Tower, G. \& Porter, S. (2015). Financial Reporting Compliance in Indonesia Local Government: Mimetic Pressure Dominates. Jurnal Akuntansi \& Auditing, 19(1), 68-84.

Aswar, K. \& Saidin, S. Z. (2018a). The influencing factors on the level of accrual accounting adoption: A conceptual approach. Romanian Economic and Business Review, 13(2), 22-28.

Aswar, K. \& Saidin, S. Z. (2018b). Accrual accounting adoption in Java municipalities: An empirical investigation. International Journal of Business and Economic Sciences Applied Research, 11(3), 24-30.

Badan Pemeriksaan Keuangan. (2019). Ikhtisar Hasil Pemeriksaan Semester I tahun 2019.

Ball, R. (2001). Infrastructure Requirements for an Economically Efficient System of Public Financial Reporting and Disclosure. Brookings-Wharton Papers on Financial Services, 127-269.

Bushman, R. M. \& Smith, A. J. (2001). Financial Accounting Information and Corporate Governance. Journal of Accounting and Economics, 32(1-3), 237-333.

Friedman, S. (2013). What We Know Can't Hurt Them: Origins Sources of Sustenance, A Survival Prospect of Budget Transparency in South Africa, Open Budgets: The Political Economy of Transparency, Participation, and Accountability. Washington DC: The Brookings Institution.

Gilligan, T. W. \& Matsusaka, J. G. (2001). Fiscal Policy, Legislature, Size, and Political Parties: Evidence from State and Local Government in the First Half of the $20^{\text {th }}$ Century. National Tax Journal, 54(1), 57-81.

Glaum, M. \& Matsusaka, J. G. (2001). Fiscal Policy, Legislature, Size, and Political Parties: Evidence from State and Local Governments in the First Half of the 20 th Century. National Tax Journal, 54(1), 57-81.

Graham, D. \& Woods, N. (2006). Making Corporate Self-Regulation Effective in Developing Countries. World Development, 34(5), 868-883.

Gore, A. K. (2004). Does Mandatory Disclosure Reduce the Cost of Capital? Evidence from Bonds. Lundquist College of Business, University of Oregon.

Hasan, T., Karim, W. \& Quayes, S. (2008). Regulatory Change and the Quality of Compliance to Mandatory Disclosure Requirements: Evidence from Bangladesh. Research in Accounting Regulation, 20, 193203.

Healy, P. M. \& Palepu, K. G. (2001). Information Asymmetry, Corporate Disclosure and the Capital Markets: A Review of the Empirical Disclosure Literature. Journal of Accounting and Economics, 31(1-3), 405440. 
Hendriyani, R. \& Tahar, A. (2015). Analysis Faktor-Faktor Yang Mempengaruhi Tingkat Pengungkapan Laporan Keuangan Pemerintah Provinsi di Indoneisa. Jurnal Bisnis dan Ekonomi (JBE), 22(1), 25-33.

Hilmi, A. Z. \& Martani, D. (2012). Analysis Faktor-Faktor Yang Mempengaruhi Tingkat Pengungkapan Laporan Keuangan Pemerintah Provinsi. Symposium Nasional Akuntansi, XV, 1-26.

Hix, S., Noury, A. \& Roland, G. (2005). Power to the Parties: Cohesion and Competition in the European Parliament. 1979-2001. British Journal of Political Science, 35(2), 209-234.

Ingram, R. W. \& DeJong, D. V. (1987). The Effect of Regulation on Local Government Disclosure Practices. Journal of Accounting and Public Policy, 6(4), 245-270.

Kaswan. (2012). Manajemen Sumber Daya Manusia untuk Keunggulan Bersaing Organisasi. Yogyakarta: Graha Ilmu.

Kompas. (2010). Laporan Keuangan Daerah Memprihatinkan.

Lambert, R., Leuz, C. \& Verrechia, R. E. (2007). Accounting Information, Disclosure and the Cost of Capital. Journal of Accounting Research, 45(2), 385-420.

Laswad, F., Fisher, R. \& Oyelere, P. (2005). Determinants of Voluntary Internet Financial Reporting by Local Government Authorities. Journal of Accounting and Public Policy, 24(2), 101-121.

Laupe, S. (2018). Role of Culture and Law Enforcement in Determining the Level of IFRS Adoption. European Research Studies Journal, 21(1), 52-64.

Martani, D. \& Lestiani, A. (2012). Disclosure in Local Government Financial Statements: The Case of Indonesia. Global Review of Accounting and Finance, 3(1), 67-84.

Marsella, C. \& Aswar, K. (2019). An investigation of financial statement disclosure in local government financial statements. International Journal of Business and Economic Affairs, 4(6), 273-281.

Mulyadi, S. (2008). Manajemen Keuangan Publik. Jakarta: Balai Pustaka.

Owusu-Ansah, S. (1998). The Impact of Corporate Attributes On the Extent of Mandatory Disclosure and Reporting by Listed Companies in Zimbabwe. International Journal of Accounting, 33(5), 605-631.

Patrick, P. A. (2007). The Determinant of Organizational Innovativeness: The Adoption of GASB 34 in Pennsylvania Local Government. Unpublished PhD Thesis. The Pennsylvania State University.

Puspita, R. \& Martani, D. (2012). Analysis Pengaruh Kinerja dan Karakteristik Pemda Terhadap Tingkat Pengungkapan dan Kualitas Informasi Dalam Website Pemda. Symposium Nasional Akuntansi XV. Banjarmasin 20-23 September 2012.

Ramandei, P., Rohman, A., Ratmono, D. \& Ghozali, I. (2019). Interactions of financial assistance and financial reporting competency: Evidence from local government in Papua and West Papua Indonesia. International Journal of Financial Research, 11(1), 1-12.

Suhardjanto, D. \& Yulianingtyas, R. R. (2011). Pengaruh Karakteristik Pemerintah Daerah Terhadap Kepatuhan Pengungkapan Wajib Dalam Laporan Keuangan Pemerintah Daerah (Studi Empiris Pada Kabupaten/Kota di Indonesia). Jurnal Akuntansi dan Auditing, 8(1), 71-94.

Suhardjanto, D. \& Lesmna, S. I. (2010). Pengaruh karakteristik pemerintah daerah terhadap tingkat pengungkapan wajib di Indonesia. Jurnal Prestasi, 6(2), 25-40.

Stigler, G. J. (1976). The Size of Legislature. The Journal of Legal Studies, 5(1), 17-34.

Wallance, R. S. O. \& Naser, K. (1995). Frim-specific determinants of the comprehensiveness of mandatory disclosure in the corporate annual reports of firms listed on the stock exchange of Hong Kong. Journal of Accounting and Public Policy, 14(4), 311-368. 